\title{
NASAB DALAM PERSPEKTIF TAFSIR AHKAM
}

\author{
M. Jamil \\ Universitas Islam Negeri (UIN) Sumatera Utara Medan \\ Jalan Williem Iskandar Pasar V, Medan Estate, Medan, Sumatera Utara 20371 \\ E-mail: jamilsiahaan@gmail.com
}

\begin{abstract}
Nasab (Family Relationship) in Perspective of Tafsîr Ahkâm (Legal Qur'anic Interpretation). Family relationship for someone is something very important. Due to this relation, people would have family relation to whom they are connected. The importance of nasab discussion because it relates someone to a lot of matters, such as inheritance, guardian, and equality (kafâa $a$ ) of husband and wife before marriage. The fiqh scholars and commentators disagree with the meaning of nasab. Many Scholars say that nasab is the relationship between a man and his child related to legal marriage. Hanafiyah states that nasab is the relationship between a man and his child due to genetic relationship. The logical consequence of this difference is in inheritance. Many scholars assert that inheritance is only connected to legitimate family relationship while Hanafiyah tend to say that inheritance is related to blood relations.
\end{abstract}

Keywords: nasab, bastard, and inheritance

\begin{abstract}
Abstrak. Nasab dalam Perspektif Tafsir Abkam. Nasab bagi seseorang merupakan sesuatu yang sangat penting. Karena dengan nasab, seseorang akan memiliki hubungan nasab kepada siapa yang ia terhubung nasabnya. Pentingnya pembahasan nasab, karena berkaitan dengan seseorang dalam banyak hal, seperti warisan, wali, kafâah suami terhadap istri dalam pernikahan dan sebagainya. Para ulama tafsir dan fikih berbeda pendapat mengenai arti nasab. Jumhur ulama mengatakan bahwa nasab adalah hubungan antara laki- laki dengan seorang anak yang mencampuri ibunya disebabkan adanya hubungan pernikahan yang sah. Hanafiyah berpendapat bahwa nasab adalah hubungan antara laki-laki dengan seorang anak karena adanya hubungan darah. Konsekuensi logis dari perbedaan ini adalah berkenaan dengan kewarisan. Jumhur ulama berpendapat bahwa kewarisan hanya melalui nasab yang sah, sementara Hanafiyah cenderung kepada adanya kewarisan disebabkan adanya hubungan darah.
\end{abstract}

Kata kunci: nasab, anak zina, dan waris

\section{Pendahuluan}

Persoalan nasab merupakan masalah yang sangat penting, tidak saja dalam kajian-kajian akademik, tetapi juga di dalam kehidupan nyata di masyarakat. Pemahaman yang berkembang di tengah-tengah masyarakat Indonesia secara umum adalah bahwa setiap anak yang terlahir dari hasil perzinaan, maka anak itu dipahami sebagai anak yang tidak memiliki hubungan nasab dengan laki-laki (bapak zinanya) yang menzinai ibu anak tersebut. Meskipun sebelum anak itu terlahir, sang ibu telah melakukan pernikahan dengan laki-laki yang menzinai ibu anak tersebut.

Pemahaman seperti itu memiliki landasan referensi yang kuat di dalam kitab-kitab fikih. Sebagai contoh, apa yang ditegaskan oleh Ibn Qudâmah, Ibn Taymiyyah, dan al-Nawâwî yang ringkasannya terhimpun dalam kutipan berikut:

Naskah diterima: 27 Juli 2015, direvisi: 10 Agustus 2015, disetujui untuk terbit: 4November 2015.
Anak zina dinasabkan kepada ibunya dan tidak dinasabkan kepada laki-laki yang menzinai ibunya (bapak zinanya). Tegasnya, hubungan nasabnya antara anak dengan bapaknya terputus. Demikian juga dengan hukum waris terputus dengan bapaknya, dia hanya mewarisi ibunya dan ibunya mewarisinya. Demikian juga hak kewalian-kalau seorang anak perempuan terputus dengan bapaknya. Yang menjadi wali nikahnya adalah sultan (penguasa) atau wakilnya seperti kadi (penghulu). Dan tidak wajib bagi bapaknya memberi nafkah kepada anak yang lahir dari hasil zina tersebut. ${ }^{1}$

Pemahaman seperti ini memiliki konsekuensikonsekuensi yang negatif. Dampak negatif pemahaman seperti ini adalah adanya kemungkinan peningkatan angka perzinaan karena seseorang (secara khusus lakilaki) yang telah melakukan perzinaan, tidak memiliki beban tanggung jawab apa-apa, meskipun memang untuk orang tertentu ada beban psikologis karena telah melakukan dosa besar.

\footnotetext{
1 "Hamil di Luar Nikah dan Masalah Nasab Anak Zina” Almanhaj. or.id/content/2099/slash/0/. Diunduh 23 Februari 2016.
} 
Dari sisi hukum positif, ada sanksi-sanksi hukum bagi pelaku kejahatan atau kekerasan seksual, itupun jika yang dizinai atau keluarganya mengambil tindakan hukum atas perzinaan tersebut. Jika tidak, maka pelaku zina merasa bebas begitu saja tidak merasa memiliki beban, sebab Islam (baca fikih) seperti yang dipahami di atas juga tidak memberikan beban tanggung jawab apa-apa kepada laki-laki yang menzinai tersebut.

Dampak negatif lainnya dari pemahaman di atas berkaitan dengan tatanan sosial kehidupan masyarakat. Dimulai dari hal-hal yang berhubungan dengan administrasi kependudukan yang bisa dianggap melawan hukum Islam, sampai kepada hal-hal yang berhubungan dengan perkawinan dan warisan, khususnya jika hal tersebut harus diselesaikan lewat jalur hukum di badan peradilan.

Karena itu, permasalahan ini perlu untuk dikaji kembali secara akademik. Bagaimana sebenarnya kedudukan nasab seorang anak yang terlahir dari perzinaan. Apakah benar seperti yang dipahami masyarakat selama ini. Ataukah ada ada pandanganpandangan lain. Untuk kepentingan dalil yang kuat dari kajian ini, maka perlu dirujuk kembali ayatayat Alquran yang berhubungan dengan nasab ini. Karena itu, tulisan ini akan merujuk kepada beberapa kitab tafsir, meskipun untuk penjelasan-penjelasan lebih lanjut merujuk kitab-kitab fikih. Tulisan ini diharapkan dapat memberikan penjelasan yang dapat dipertanggungjawabkan tentang bagaimana sebenarnya kedudukan nasab seorang anak yang terlahir dari sebuah perzinaan dan apa yang menjadi haknya dalam bidang kewarisan.

\section{Ayat-ayat Alquran tentang Nasab}

Kata nasab disebutkan di dalam Alquran pada 3 (tiga) tempat yaitu pada surah al-Muminûn ayat 101, surah al-Furqân ayat 54 dan al-Shâffât ayat 158.

Surah al-Müminûn ayat 101:

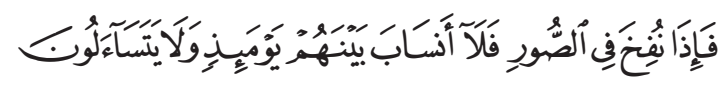

Apabila sangkakala ditiup maka tidaklah ada lagi pertalian nasab di antara mereka pada hari itu, dan tidak ada pula mereka saling bertanya”.

Surah al-Furqân ayat 54:

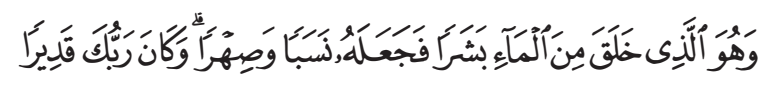

Dan Dia (pula) yang menciptakan manusia dari air, lalu Dia jadikan manusia itu (punya) keturunan dan mushâharah dan adalah Tuhanmu Maha Kuasa.
Surah al-Shâffât ayat 158:

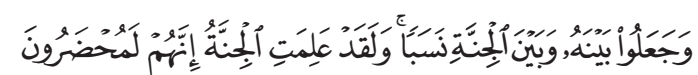

Dan mereka adakan (hubungan) nasab antara Allah dan antara jin. dan Sesungguhnya jin mengetahui bahwa mereka benar-benar akan diseret (ke neraka).

Ketiga ayat di atas memperlihatkan dengan jelas bahwa nasab mempunyai makna yang sangat penting, sampai-sampai di akhirat pun manusia menduga bahwa hubungan nasab tersebut masih sangat perlu. Mereka menduga ketika itu (akhirat) hubungan nasab dapat membantu menyelesaikan masalah-masalah besar yang sedang dan akan dihadapi. Di dalam ayatayat tersebut, dijelaskan bahwa bahwa tidak ada lagi hubungan nasab di antara mereka ketika itu (akhirat). Ini sekaligus menggambarkan bahwa masalah nasab ini diakui atau ditegaskan Allah urgensinya di dalam ke hidupan dunia, tetapi tidak ada relevansinya lagi di dalam kehidupan akhirat, khususnya dalam hal-hal yang tidak diberi izin oleh Allah Swt. Hal-hal yang diberi izin oleh Allah seperti yang ditegaskan di dalam pelbagai sunah, seseorang dapat memberi faidah dan mudarat kepada orang lain ketika di depan pengadilan Allah Swt. Tegasnya, dalam Alquran terlihat bagaimana masalah nasab ini menjadi sesuatu yang penting.

\section{Nasab dalam Tafsir Alquran}

Secara etimologi, nasab berasal dari bahasa Arab, yaitu nasaban نَ dan merupakan deviasi dari kata nasabayansibu-nasaban yang berarti kerabat, keturunan atau menetapkan keturunan ${ }^{2}$. Ulama tafsir berbeda pendapat mengenai arti nasab. Husnaini dalam kitabnya, Kalimat Alquran Tafsîr wa Bayân, menjelaskan,

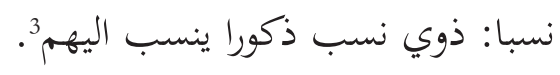

Orang yang punya hubungan nasab dari pihak laki- laki yang dinasabkan kepada mereka.

$$
\text { صهرا: ذوات صهر إناثا يصاهر .كن. }
$$

Orang yang mempunyai hubungan dari pihak perempuan karena ada hubungan perkawinan (mushâharah) dengan mereka”.

Al-Râgib al-Ashfahâni menjelaskan bahwa nasab adalah isytirâk min jihhah ahad al-abawain اشتراك من جهة persekutuan, hubungan, keterkaitan antara anak dengan salah satu dari kedua orang tuanya. ${ }^{5}$

\footnotetext{
${ }^{2}$ Ibn Mandzur, Lisân al-Arab, (Kairo: Dâr al-Maârif, t.t), h. 4405.

3 Husnaini Muhammad Makhluf, Kalimat Alquran Tafsîr wa Bayân, (Qâhirah: Dâr al-Qalam, 1956), h. 128.

${ }^{4}$ Husnaini Muhammad Makhluf, Kalimat Alquran Tafsîr wa Bayân, h. 128.

5 al-Râgib al-Ashfahâni, Mujjam Mufradat al-Faz Alquran, (Beirut:
} 
Sedangkan Ibnu Kasîr mengartikan nasab dengan hubungan turun temurun membentuk keluarga-keluarga lewat hubungan yang berasal dari perkawinan. ${ }^{6}$ Pendapat lain dikemukan Al-Thabâthabâii, secara umum ia menerangkan di dalam tafsirnya bahwa nasab adalah hubungan atau ikatan yang menghubungkan atau mengikat seseorang dengan yang lain berdasarkan kelahiran/hubungan darah, wiladah (جلادة) dan sekandung, jâmi'al-rahm (جامع الرحم). ${ }^{7}$

Abi Husain Ahmad Ibnu Faris Zakaria, menyebutkan bahwa arti nasab ialah ittishâlu syai in bi syaiin (تصال (شئ بشئ), hubungan sesuatu dengan sesuatu yang lain. ${ }^{8}$ M. Mutawali Syàrawi memahaminya sebagai berikut, disebabkan nasab adalah proses pindahnya dari bawah ke atas dari pria, menjadilah si fulan bin fulan. Nasab berasal dari pihak pria. ${ }^{9}$ Sedangkan M. Quraish Shihab mengartikan nasab hanya sebagai bentuk keturunan dari laki- laki. ${ }^{10}$

Ketika menafsirkan surah al-Furqân ayat 54, Wahbah al-Zuhaylî memberikan penjelasan mengenai nasab sebagai berikut:

$$
\begin{aligned}
& \text { وإذا لم يكن النسب ثابتا شرعا لم تثبت حرمة المصاهرة, } \\
& \text { وعليه قال الجمهور : إذا لم يكن نسب شرعا, فلا صهر }
\end{aligned}
$$

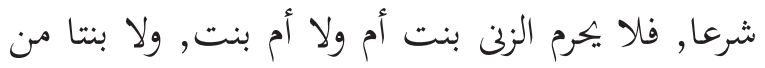

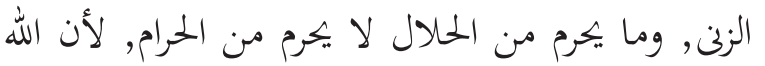

$$
\begin{aligned}
& \text { امتن بالنسب و الصهر على عباده, و رفع قدرهما, وعلق }
\end{aligned}
$$

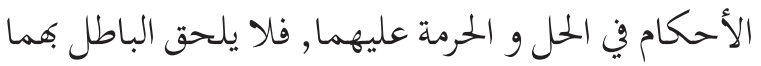

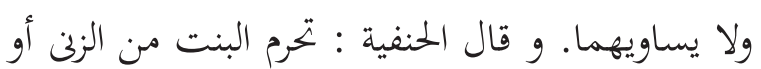

$$
\begin{aligned}
& \text { الأخت أو بنت الابن من الزنى, بسبب التولد من ماء الحنية }
\end{aligned}
$$

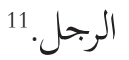

Jika nasab tidak ditetapkan sesuai dengan dengan prosedur syara' maka bagaimana mungkin shahr (hubungan kekerabatan dikarenakan perkawinan) ditetapkan dengan syara'. Menurut pendapat ulama jumhur, jika nasab tidak ditetapkan dengan syara' maka mushaharah tidak ditetapkan dengan syara', maka tidak

Dâr al-Kutub al- Ilmiyah, 2013), h. 545. Lihat juga di Ensiklopedia Alquran, Kajian Kosa Kata, (Jakarta: Lentera Hati, 2007), h. 710.

${ }^{6}$ Ibnu Kasîr, Tafsîr Ibnu Kasir, diterjemahkan oleh Salim Bahreisy, Said Bahreisy, (Surabaya: PT Bina Ilmu, 2005), h. 27.

${ }^{7}$ Ensiklopedia Al-qur'an, Kajian Kosa Kata, h. 710.

${ }^{8}$ Abi Husain Ahmad Ibnu Faris Zakaria, Maqâyis al-Lughah, Jilid V, (Beirut: Dâr al-Fikr, th), h. 423.

${ }^{9}$ Muhammad Mutawali Syảrawî, Tafsìr Sya'rawî, Jilid 9, (Jakarta: PT Khazanah Nusantara Agung, 2011), h. 770.

${ }^{10}$ M. Qurasih Shihab, Tafsir al-Mishbah, Pesan, Kesan, dan Keserasian Alquran, (Jakarta: Lentera Hati, 2002), h. 503.

${ }^{11}$ Wahbah al-Zuhaylîi, Tafsîr al-Munîr fi al-Aqidah wa Syariah wa al-Manhaj, Juz 10, (Beirut: Dâr al- Fikr, 2011), h. 96. mengharamkan zina anak perempuan ibu dan tidak ibu anak perempuan dan juga tidak anak dari prempuan yang dizinai, apa yang diharamkan dari yang halal tidak diharamkan dari yang haram. Karena Allah telah menganugerahkan nasab dan shahr atas hamba-Nya dan Allah mengangkat derajat keduanya. Dan Allah menggantungkan hukum-hukum yang halal dan yang haram atas keduanya, maka tidak boleh menghubungkan yang batal dengan keduanya dan tidak boleh pula menyamakannya dengan yang batal. Hanafiyah berpendapat diharamkan menikahi anak perempuan hasil zina atau saudari zina atau anak perempuan dari anak zina karena disebabkan terlahir dari air mani laki-laki yang menzinahinya.

Al-Qurthubî, di dalam tafsirnya mengatakan bahwa nasab adalah kata yang digunakan untuk mengungkapkan percampuran di antara sperma laki-laki dan ovum perempuan berdasarkan prosedur syara. Dengan demikian, menurut suatu pendapat, anak yang merupakan hasil dari percampuran antara sperma lakilaki dan ovum prempuan yang tidak melalui prosedur syara', maka di antara yang melahirkan dan dilahirkan tidak memiliki terkaitan nasab. ${ }^{12}$

Konsekuensi logis dari pengertian di atas ialah adanya perbedaan pendapat di antara para ahli tafsir dan fikih tentang hubungan keturunan atau nasab di antara bapak dan anak zinanya. Hanafiyah, misalnya, sebagai dikutip oleh al-Qurthubî, mengakui adanya nasab (hubungan keturunan) di antara mereka, sedangkan Syâfi'iyyah menganggap tidak ada hubungan nasab antara bapak dan anak zinanya. Konsekuensi hukumnya adalah bahwa kelompok pertama harus mengakui adanya hubungan kewarisan di antara mereka, sedangkan kelompok kedua tidak demikian, karena telah disepakati bahwa kewarisan hanya melalui nasab atau wala' (ولاء) dan mushâharah (مصا هرة) hubungan semenda.

\section{Nasab Anak}

Dalam kamus bahasa Arab, Ibn Sidah mengatakan, sebagaimana dikutip oleh Ibn Manzur, bahwa "anak disebut dengan kata al-walad dan al-wuldu yang berarti setiap anak yang dilahirkan baik laki-laki maupun perempuan, dan bentuk jamaknya berupa aulad, wildah, dan ildah." "13 Ali al-Shabuni berpendapat bahwa "al-walad mencakup anak laki-laki dan perempuan, dan kata "ibn" khusus untuk anak laki-laki." ${ }^{14}$ Sedangkan dalam kamus bahasa Indonesia, kata nasab yang diadopsi dari bahasa Arab tidak mengalami pergeseran arti yang signifikan. Nasab diartikan dengan keturunan

${ }^{12}$ Ensiklopedia Al-Qur'an, Kajian Kosa Kata. h. 710.

${ }^{13}$ Ibn Manzur, Lisân al-'Arab, (Kairo: Dâr al-Ma'ârif, t.t), h. 4914.

${ }^{14}$ Muhammad Ali al-Shabûnî, Min Qumush al-Sunnah, (Jakarta: Dâr al-Kutub al-Islâmiyyah, 1999), h. 128. 
(terutama pihak bapak) atau pertalian keluarga. ${ }^{15}$

Wahbah al-Zuhaylî mendefinisikan nasab sebagai suatu sandaran yang kokoh untuk meletakkan suatu hubungan kekeluargaan berdasarkan kesatuan darah atau pertimbangan bahwa yang satu adalah bagian dari yang lain. Misalnya, seorang anak adalah bagian dari ayahnya, dan seorang ayah adalah bagian dari kakeknya. Dengan demikian, orang-orang yang serumpun nasab adalah orang-orang yang satu pertalian darah. ${ }^{16}$ Lebih lanjut, Wahbah al-Zuhaylî menegaskan bahwa "hubungan nasab seorang anak ditetapkan kepada ibunya dalam keadaan apapun baik dilahirkan secara syar'i atau tidak." ${ }^{17}$ Penjelasan ini berbeda pada pendapat ulama umumnya bahwa anak memiliki hubugan nasab kepada ayahnya. Pendapat Wahbah al-Zuhaylî yang menghubungkan nasab anak kepada ibunya, sama halnya dengan penetapan nasab kepada anak zina yang hanya memiliki nasab kepada ibunya saja.

Penjelasan pengertian nasab tersebut dapat dipahami bahwa nasab itu berarti hubungan darah antara seseorang dengan yang lainnya, baik jauh maupun dekat. Namun, jika membaca literatur hukum Islam, maka kata nasab itu akan menunjuk pada hubungan keluarga yang sangat dekat, yaitu hubungan anak dengan orang tua, terutama orang tua laki-laki.

Urgensi pembahasan nasab dalam Islam, dilihat ketika Nabi Muhammad Saw. mengangkat seorang anak yang bernama Zaid bin Haritsah. Kemudian ia, dinasabkan kepada Nabi. Hal itu mendapatkan keteguran dari Allah Swt, dalam Alquran surah alAhzâb ayat 4-5 yang berbunyi:

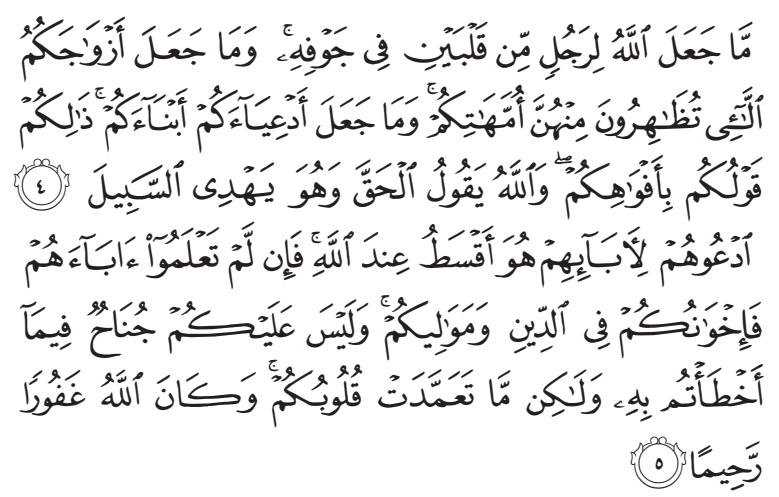

Allah sekali-sekali tidak menjadikan bagi seseorang dua buah hati dalam rongganya; dan dia tidak menjadikan istri-istrimu yang kamu zhihar itu sebagai ibumu, dan dia tidak menjadikan anak-anak angkatmu sebagai anakanak kandungmu (sendiri). Yang demikian itu hanyalah perkataanmu di mulut saja. Dan Allah mengatakan yang

${ }^{15}$ Poerwadarminta, Kamus Umum Bahasa Indonesia, (Jakarta : PN Balai Pustaka, 1966), h. 672.

${ }^{16}$ Wahbah al-Zuhaylî, al-Fiqh al-Islâmî wa Adillatuh, h. 7247.

${ }^{17}$ Wahbah al-Zuhaylî, al-Fiqh al-Islâmî wa Adillatuh, h. 7247. sebenarnya. Dan Dia menunjukkan jalan (yang benar). Panggillah mereka (anak-anak angkat itu) dengan (memakai) nama bapak-bapak mereka, itulah yang lebih adil pada sisi Allah, dan jika kamu tidak mengetahui bapak-bapak mereka, maka (panggillah) mereka sebagai saudara-sauadaramu seagama dan maula-maulamu. Dan tidak ada dosa atasmu terhadap apa yang kamu khilaf kepadanya, tetapi (yang ada dosanya) apa yang disengaja oleh hatimu. Dan adalah Allah Maha Pengampun lagi Maha Penyayang.

Ayat di atas menjelaskan bahwa tidak dibenarkan anak angkat menjadi anak kandung dan anak angkat tetap dinasabkan kepada ayah kandungnya. Karena, anak angkat tidak dilahirkan dari keturunan orang tua angkat tersebut. Demikian perhatian Alquran terhadap permasalahan nasab ini.

\section{Sebab-sebab Ditetapkan Nasab}

Wahbah al-Zuhaylî mengatakan sebab-sebab ditetapkannya nasab:

$$
\begin{aligned}
& \text { سبب ثبوت نسب الولد من أمه: هو الولادة, شرعية } \\
& \text { كانت أم غير شرعية. } \\
& \text { و أما أسباب ثبوت النسب من الأب فهو: } \\
& \text { ا ـ الزواج الصحيح } \\
& \text { r ب الزواج الفاسد }
\end{aligned}
$$

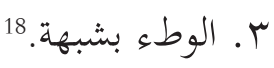

Teks di atas menjelaskan bahwa tetapnya nasab seorang anak kepada ibunya adalah dikarenakan kelahiran (wilâdah), baik secara syariat maupun tidak. Bahwa "sebab-sebab ditetapkannya nasab seorang anak kepada ayahnya, yaitu: pernikahan yang sah (al-zawâj al-shahîh), pernikahan yang rusak (al-zawâj al-fâsid), dan persetubuhan subhat (al-wath'u bi al-syubhah)." Sebagaimana penjelasan berikut:

Pertama, pernikahan yang sah (al-zawâj al-Shahihih).

$$
\text { زتفق الفقهاء على أن الولد الذي تأتى به المرأة المتزوجه }
$$

Para ahli fikih sepakat bahwa seorang anak yang terlahir dari seorang perempuan melalui perkawinan yang sah, maka si anak dinasabkan kepada suami dari perempuan tersebut.

Para ulama fikih sepakat bahwa akad perkawinan yang sah merupakan sebab dalam ketetapan nasab seorang anak. ${ }^{20}$ Dengan demikian, anak-anak yang

\footnotetext{
${ }^{18}$ Wahbah al-Zuhaylî, al-Figh al- Islamî wa Adillatuh, h. 7256.

${ }^{19}$ Wahbah al-Zuhaylî, al-Figh al- Islamî wa Adillatuh, h. 7256.

${ }^{20}$ Ahmad Farraj Husain, Ahkâm al-Usrah fi al-Islâm, (Beirut: Dâr al-Jami'iyyah, 1998), h. 248.
} 
lahir dari perempuan itu dalam hubungan perkawinan yang sah adalah benar-benar anak sang suami, tanpa memerlukan adanya tuntutan ibu agar suami mengakui anak yang dilahirkannya adalah anaknya. Penetapan hubungan kekerabatan tersebut di atas yang dapat dijadikan mazhinnah-nya adalah akad nikah yang sah, yang telah berlaku antara seorang laki-laki dan perempuan yang melahirkan anak tersebut. Selanjutnya, akad nikah tersebut yang menjadi faktor penentu hubungan kekerabatan itu. Oleh karena itu, dapat dikatakan bahwa hubungan kekerabatan yang diakui antara seseorang anak dengan seseorang laki-laki sebagai ayahnya, apabila anak tersebut lahir dari hasil atau akibat perkawinan yang terjadi antara laki-laki dengan perempuan yang melahirkannya.

Kedua, pernikahan yang rusak (al-zawâj al-fâsid).

$$
\text { الزواج الفاسد في إثبات النسب كالزواج الصحيح.21 }
$$

Pernikahan fâsid ialah pernikahan yang dilangsungkan dalam keadaan cacat syarat sahnya. Penetapan nasab dalam pernikahan yang rusak (fâsid) sama seperti pernikahan yang sah. Pernikahan fâsid, seperti tidak adanya wali dalam pernikahan (dalam mazhab Hanafi, wali tidak termasuk dalam syarat sahnya perkawinan) dan tidak ada saksi atau saksinya itu adalah saksi palsu.

Pernikahan yang rusak (al-zawâj al-fâsid) menurut ulama Mazhab Hanafi ada enam macam, yaitu, (1) nikah tanpa saksi; (2) nikah mutah, (3)Nikah dengan cara menghimpun wanita lima sekaligus; (4) nikah dengan menghimpun seorang perempuan dengan bibinya atau seorang perempuan dengan saudari kandungnya; (5) nikah dengan wanita yang telah punya suami;(6) nikah dengan seorang mahram. ${ }^{22}$

Sedangkan Mazhab Malik bahwa macam-macam nikah fâsid adalah, (1) nikah dengan mahram; (2) nikah dengan cara menghimpun dua wanita bersaudara; (3) nikah dengan istri sebagai istri kelima, sedangkan istri lain masih dalam akad; (4) nikah mutah; (5) nikah dengan wanita yang masih dalam idah. ${ }^{23}$

Nikah fâsid menurut Imam Syafi'I adalah, (1) nikah shigar; (2) nikah mutah; (3) nikah dalam masa ihram; (4) poliandri; (5) nikah dengan wanita yang masih dalam masa idah atau itibra; (5) nikah dengan wanita dalam keadaan hamil; (6) Nikah dengan wanita wanita non-Muslim yang bukan ahli kitab; (7) mnikah

${ }^{21}$ Wahbah al-Zuhaylî, al-Figh al- Islamî wa Adillatuh., h. 7261.

${ }^{22}$ Andi Syamsu Alam dan M. Fauzan, Hukum Pengangkatan Anak Perspektif Hukum Islam, (Jakarta: Kencana Prenada Media Group, 2008), h. 184.

${ }^{23}$ Andi Syamsu Alam dan M. Fauzan, Hukum Pengangkatan Anak PerspektifHukum Islam, h. 184. dengan wanita yang selalu pindah-pindah agama; (7) Menikahkan dengan lelaki kafir atau menikah dengan wanita murtad. ${ }^{24}$

Sedangkan dalam Mazhab Hambali kategori nikah fâsid yaitu, (1) nikah shigar; (2) nikah muhallil, (3) nikah muballil, (4) nikah mut'ah (5) nikah mu'aqqat (yaitu nikah yang dihubungkan dengan suatu kondisi). ${ }^{25}$

Para ulama sepakat bahwa penetapan nasab anak yang lahir dalam perkawinan fasid sama dengan penetapan nasab anak yang lahir dalam perkawinan yang sah. ${ }^{26}$

Ketiga, persetubuhan syubhat (al-Wath'u bi alSyubhah). Al-syub $\underline{h} a h$ berarti kemiripan, keserupaan, persamaan, dan ketidak jelasan. Dalam kaitannya dengan kajian hukum, istilah syubhah dapat diinterpretasikan sebagai situasi dan kondisi adanya ketidakjelasan dalam sebuah peristiwa hukum. Hal itu karena ketentuan hukumnya tidak dapat diketahui secara pasti, apakah berada dalam wilayah halal atau haram.

Dalam pengertian lain, syubbahah adalah sesuatu yang tidak jelas apakah benar atau tidak, atau masih mengandung probabilitas antara benar dan salah, sekaligus tidak bisa ditarjihkan mana yang validitas hukumnya lebih kuat. ${ }^{27}$

Wahbah al-Zuhaylî, menjelaskan:

$$
\begin{aligned}
& \text { الوطء بشبهة: هو الاتصال الجنسي غير الزنا, وليس } \\
& \text { بناء على عقد زواج صحيح أو فاسد, مثل المرأة المزفوفة } \\
& \text { إلى بيت زوجها دون رؤية سابقة, و قيل : إها زوجته, } \\
& \text { فيدخل بها. و مثل وطء امرأة يجدها الرجل على فراشة, } \\
& \text { فيظنها زوجته.ومثل وطء المطلقة طلاقا ثلاثا أثناء } \\
& \text { العدة, على اعتقاد أها تحل له. } 28
\end{aligned}
$$

Persetubuhan atau senggama syubhah ialah hubungan jenis antara laki-laki dan perempuan (bukan zina), dan bukan dibangun melalui akad perkawinan yang sah atau rusak, seperti seorang perempuan yang bergegas ke rumah suaminya tanpa memastikan terlebih dahulu, dan dikatakan bahwa ia istrinya. Kemudian ia menyetubuhinya, dan seperti senggamanya seorang perempuan yang dijumpai oleh seorang laki-laki diatas kasurnya, kemudian ia mengira perempuan tersebut

\footnotetext{
${ }^{24}$ Andi Syamsu Alam dan M. Fauzan, Hukum Pengangkatan Anak Perspektif Hukum Islam, h. 184.

${ }^{25}$ Andi Syamsu Alam dan M. Fauzan, Hukum Pengangkatan Anak Perspektif Hukum Islam, h. 184.

${ }^{26}$ Andi Syamsu Alam dan M. Fauzan, Hukum Pengangkatan Anak Perspektif Hukum Islam, h. 184.

${ }^{27}$ Andi Syamsu Alam dan M. Fauzan, Hukum Pengangkatan Anak Perspektif Hukum Islam, h. 185.

${ }^{28}$ Wahbah al-Zuhaylîi, al-Fiqh al-Islamî wa Adillatuh., h. 7263.
} 
istrinya. Apabila seorang perempuan yang disenggama melahirkan anak pada waktu setelah enam bulan atau lebih dari waktu senggama, maka nasab anak tersebut ditetapkan kepada orang yang menyetubuhinya dengan adanya keyakinan bahwa kehamilan dikarenakannya.

\section{Cara Penetapan Nasab}

Nasab seorang anak yang dilahirkan dapat ditetapkan kepada ayahnya melalui salah satu dari tiga cara. ${ }^{29}$ Pertama, pernikahan yang sah atau rusak (al-zawâj al-shahih aw alfâsid). Pernikahan yang sah atau rusak merupakan sebab ditetapkannya nasab, dan cara menetapkan nasabnya yaitu secara realistis, kapanpun pernikahan ditetapkan walaupun pernikahan fasid, atau pernikahan menurut kebiasaannya seperti orang yang melaksanakan akad pernikahan dengan cara akad secara khusus yaitu tanpa melalui pihak pencatat nikah, maka setiap anak yang dilahirkan oleh setiap wanita dapat ditetapkan nasabnya. Ulama fikih sepakat bahwa nikah yang sah atau fassid merupakan salah satu cara dalam menetapkan nasab seorang anak kepada ayahnya, sekalipun pernikahan dan kelahiran anak tidak didaftarkan secara resmi pada instansi terkait. ${ }^{30}$

Kedua, pengakuan nasab atau pengakuan anak. Ikrar bi al-nasab merupakan salah satu cara untuk penetapan nasab. Ikrar bi al-nasab ada dua macam, yaitu: (1) pengakuan nasab untuk diri sendiri; (2) pengakuan yang mencakup untuk orang lain.

Ketiga, bukti. Bukti merupakan argumentasi transitif yang dampaknya tidak hanya terbatas pada terdakwa saja, akan tetapi dapat ditetapkan dalam haknya maupun hak lainnya. Penetapan nasab melalui bukti lebih kuat dari penetapan nasab melalui ikrar bi alnasab karena penetapan nasab yang sudah ditetapkan melalui ikrar dapat menjadi batal apabila ditetapkan melalui adanya bukti. ${ }^{31}$

Penetapan nasab dengan cara bukti, memberi peluang besar bahwa anak yang tidak di ketahui siapa orang tuanya, atau orang tua yang tidak mengakui anaknya, dapat dibuktikan dengan alat bukti. Pembuktian ini tentunya memberi jalan kepada jaminan kesejahteraan anak karena akan berdampak pada hak-hak anak dari orang tuanya.

\section{Akibat yang Timbul dari Hubungan Nasab}

Perlu ditegaskan di sini bahwa nasab mempunyai kedudukan yang penting dalam hukum Islam. Akibat

${ }^{29}$ Andi Syamsu Alam dan M. Fauzan, Hukum Pengangkatan Anak Perspektif Hukum Islam, h. 690-695.

${ }^{30}$ Andi Syamsu Alam dan M. Fauzan, Hukum Pengangkatan Anak Perspektif Hukum Islam., h. 186.

${ }^{31}$ Wahbah al-Zuhaylî, al-Figh al- Islamî wa Adillatuhu.,h. 690695. yang ditimbulkan dari adanya hubungan nasab adalah hubungan keperdataan dalam keluarga yang meliputi masalah mawaris, hubungan kekerabatan/mahram dan masalah perwalian.

Pertama, dalam hal waris. Nasab atau keturunan bisa menjadi sebab beralihnya harta seseorang yang telah meninggal kepada yang masih hidup. Sebagaimana yang telah diketahui bahwa sebab untuk menjadikan seseorang bisa mendapatkan hak waris yaitu ${ }^{32}$, (1) hubungan kerabat (yang ada pertalian seperti kedua orang tua, anak, saudara, paman dan seterusnya. Sebagaimana dijelaskan dalam surah al-Nisa' ayat 7 :

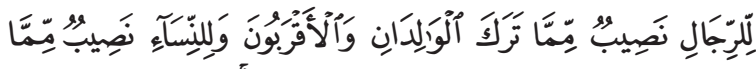

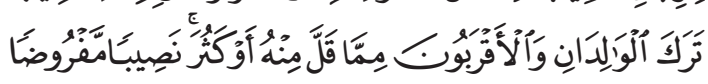

Bagi orang laki-laki ada hak bagian dari harta peninggalan ibu bapak dan kerabatnya, dan bagi orang wanita ada hak bagian (pula) dari harta peninggalan ibu-bapak dan kerabatnya, baik sedikit atau banyak menurut bahagian yang telah ditetapkan. (Q.s. al- Nisa': 7).

Kedua, al-walâ,, yaitu kekerabatan karena sebab hukum. Walâ’ oleh syariat digunakan untuk memberikan dua pengertian, Walâ' dalam arti pertama disebut dengan walâul atawqah atau ushubab sababiyah, yakni ushubah yang bukan disebabkan karena adanya pertalian nasab, tetapi disebabkan karena adanya sebab telah memerdekakan budak.

Walâ' dalam arti yang kedua disebut dengan walâulmu'awalah misalnya seseorang telah berjanji kepada orang lain. sebagai berikut, "Hai saudara, engkau adalah tuanku yang dapat mewarisi aku bila aku telah mati dan dapat mengambil diyah untukku bila aku dilukai seseorang”. Kemudian orang lain yang diajak berjanji menerima janji itu. Pihak pertama disebut dengan al-adnâ dan pihak yang kedua disebut dengan al-mawala atau al-maula. ${ }^{33}$

Ketiga, hubungan mahram. Ma $\underline{\text { hram }}$ adalah orang yang haram untuk dinikahi karena adanya sebab keturunan, persusuan, dan pernikahan dalam syariat Islam. Jadi, orang yang mempunyai pertalian nasab tidak boleh dinikahi. Sebagaimana dalam Alquran surah al-Nisầ ayat 23:

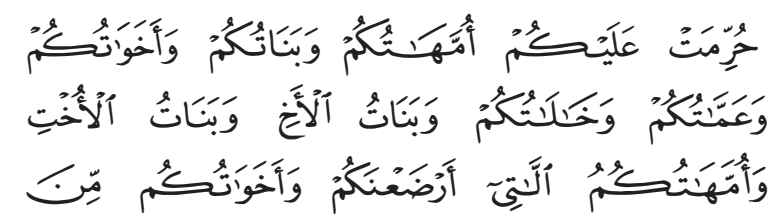

\footnotetext{
${ }^{32}$ Beni Ahmad Saebani, Figh Mawaris, (Bandung : Pustaka Setia 2009). h. 109

33 Tengku Muhamad Hasbi Ash Shiddieqi, Fiqih Mawaris, (Semarang : PT Pustaka Riski Putra, 1997), h. 28
} 


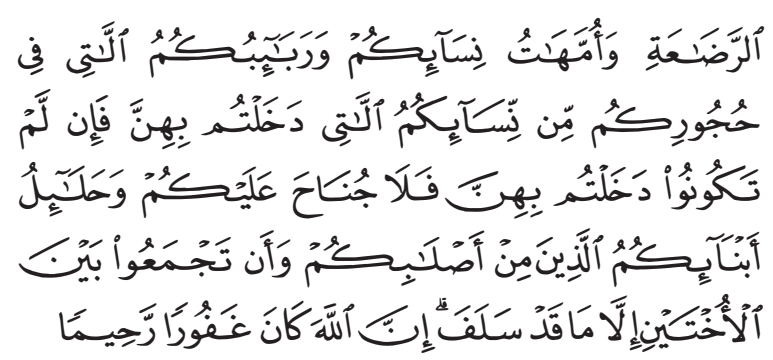

Diharamkan atas kamu (mengawini) ibu-ibumu; anakanakmu yang perempuan; saudara-saudaramu yang perempuan, saudara-saudara bapakmu yang perempuan, saudara-saudara ibumu yang perempuan, anak-anak perempuan dari saudara-saudaramu yang laki-laki, anakanak perempuan dari saudara-saudaramu yang perempuan, ibu-ibumu yang menyusui kamu; saudara perempuan sepersusuan, ibu-ibu istrimu (mertua), anakanak istrimu yang dalam pemeliharaanmu dari istri yang telah kamu campuri, tetapi jika kamu belum campur dengan istrimu itu (dan sudah kamu ceraikan), maka tidak berdosa kamu mengawininya, (dan diharamkan bagimu) istri-istri anak kandungmu (menantu), dan menghimpunkan (dalam perkawinan) dua perempuan yang bersaudara, kecuali yang telah terjadi pada masa lampau; Sesungguhnya Allah Maha Pengampun lagi Maha Penyayang. (Q.s. An-Nisa' : 23).

\section{Cara Menentukan Nasab pada Masa Modern}

Di era modern saat ini, menentukan nasab (tentunya dalam arti adanya ikatan darah) selain dengan melihat anak yang lahir dari perkawinan yang sah, juga bisa dilakukan dengan tes DNA (deoxyribo nucleic acid). Tes ini bukan merupakan hal baru dalam lapangan sains. Namun bila, persoalan tes ini dikaitkan dengan agama, tentu akan menjadi suatu persoalan yang menarik untuk dibahas. Karena mengenai hal ini terdapat perbedaan pendapat di antara para ulama, yaitu ada yang membenarkan dan ada yang tidak memperbolehkan, sebagaimana yang telah dijelaskan sebelumnya.

Pembuktian anak kandung melalui tes DNA adalah berdasarkan teori dan praktik ilmu genetika umat manusia. Kesamaan di bidang struktur bentuk dan fungsi fisiologi dari generasi ke generasi dianalissi terhadap kecirian keturunan, untuk memastikan hubungan kandung yang mencurigakan antara bapak dan anak atau ibu dan anak.

Sedangkan cara pembuktian anak kandung dari ilmu forensik sebagai berikut, pembuktian melalui tipe darah, perbandingan melalui ciri wajah, pemeriksaan terhadap kurai atau barik-barik kulit, pemeriksaan penyakit keturunan, perbedaan corak, serta membuat inferensi terhadap stadium pembuahan, periode melahirkan dan kemampuan reproduksi. ${ }^{34}$

${ }^{34}$ Kang Ari Tea, "Penyusunan Silsilah, Nasab dan Urgensinya" https:// www.facebook.com/notes/kang-ari-tea/penyusunan-silsilah-nasab-danurgensinya/10152153520621715, diunduh 23 November 2015
Tes DNA itu merupakan penemuan pada ilmu kedokteran terkini. Sebab pada zaman rasul dan sahabat belum dikenal istilah seperti itu.Yang ada pada saat itu adalah sistem al-qiyâfa, yakni menurut penglihatan setelah melihat bagian-bagian pada bayi yang baru lahir. Dan salah satu contohnya atau yang saat ini telah di-qiyas-kan adalah dalam bentuk sidik jari. Melalui sidik jari tersebut, seseorang ditentukan bahwa inilah sebenarnya hubungannya. Dalam tes DNA, akurasi tingkat kebenaran sudah mencapai 99,9 persen, dan bisa dijadikan sebagai penetapan bahwa seseorang itu memiliki hubungan dengan yang lain. Oleh karena itu, dalam penetapan nasab/keturunan, hasil tes DNA dapat dijadikan sebagai bagian yang akan mendukung boleh tidaknya seseorang itu diakui sebagai nasab. ${ }^{35}$

Tes DNA itu hanya merupakan salah satu alat untuk bisa mengetahui bahwa yang bersangkutan itu memiliki hubungan atau tidak memiliki hubungan dengan yang lain atau tidak (menafikan). Tes DNA didasarkan pada hadis nabi yang menyatakan soal qoif, yaitu orang yang bisa memprediksi secara akurat bahwa seseorang masih punya nasab dengan orang lain hanya berdasarkan bekas tapak kaki mereka. Dalil tentang qo'if ini yang kemudian dijadikan rujukan kiai-kiai yang menerima tes DNA sebagai sumber baru. ${ }^{36}$

Pertemuan ke-16 Komite Fikih Islam yang digelar di Mekah pada 2002 dan dihadiri oleh ulama dan pakar di bidang kedokteran, menghasilkan beberapa rekomendasi terkait penggunaan DNA untuk memastikan nasab, antara lain, yaitu DNA digunakan dengan penuh kehati-hatian dan prosedur yang ketat. ${ }^{37}$ Kaidah penetapan nasab yang telah diakui syariat harus lebih di kedepankan.

Yusuf al-Qaradhawi berpendapat DNA tidak bisa dijadikan bukti pengukuhan nasab dari hasil perbuatan zina. Meskipun syariat menekankan pentingnya pengukuhan nasab, tetapi khusus dalam kasus zina, hal itu harus ditutupi. Menutupi aib dari zina penting dilakukan agar tatanan sosial masyarakat Muslim tetap terjaga dan tindakan keji tersebut. Sehingga hal tidak menjalar dan menjadi hal biasa di tengah-tengah masyarakat. ${ }^{38}$

\footnotetext{
${ }^{35}$ Kang Ari Tea, "Penyusunan Silsilah, Nasab dan Urgensinya" https://www.facebook.com/notes/kang-ari-tea/penyusunan-silsilahnasab-dan-urgensinya/10152153520621715, diunduh 23 November

${ }^{36}$ Kang Ari Tea, "Penyusunan Silsilah, Nasab dan Urgensinya" https://www.facebook.com/notes/kang-ari-tea/penyusunan-silsilahnasab-dan-urgensinya/10152153520621715, diunduh 23 November

37 “DNA Buki Hubungan Nasab, Benarkah?"http://www. republika.co.id/berita/dunia-islam/fatwa/13/01/29/mhdnq0-dnabukti-hubungan-nasab-benarkah, diunduh 23 November 2015.

38 “DNA Buki Hubungan Nasab, Benarkah?"http://www.
} 2015 2015 


\section{Penutup}

Di kalangan ulama tafsir dan fikih terjadi perbedaan pendapat tentang apakah hubungan nasab sesorang dengan orang lain itu dikarenakan adanya akad yang sah antara ibu dengan ayahnya, seperti pendapat mayoritas ulama, atau dikarenakan adanya hubungan darah/biologis meskipun tidak melalui akad yang sah.

Dari kalangan empat mazhab, Imam Abu Hanifah pendiri mazhab Hanafi yang paling shârih (eksplisit) menegaskan sahnya status anak zina dinasabkan pada bapak biologisnya apabila kedua pezina itu menikah sebelum anak lahir. Ibnu Qudamah dalam al-Mugni mengutip pandangan Abu Hanifah. Karena nasabnya (anak zina tersebut) dihubungkan kepada bapak biologisnya (bapak zinanya) yang telah melangsungkan perkawinan dengan ibu yang mengandungnya sebelum ia (anak zina tersebut) dilahirkan, maka anak tersebut akan memperoleh warisan dari bapak zinanya. Oleh karena itu, nasabnya yang demikian, maka anak tersebut mendapatkan hak-haknya sebagai anak, seperti halnya hak warisan.

Pendapat tersebut menjadi penting untuk diambil perhatian, di samping agar seseorang bertanggung jawab dengan perbuatannya (zina), yang sekaligus juga dapat membantu pemerintah di dalam mengatur pelbagai persoalan kemasyarakatan yang ada kaitannya dengan masalah nasab. Begitupun, permasalahan ini perlu dikaji lebih lanjut, dengan memperhatikan dalil-dalil lainnya baik dari Alquran, Sunah, dan kemaslahatan yang lebih besar. []

\section{Pustaka Acuan}

Ensiklopedia Alquran, Kajian Kosa Kata, Jakarta: Lentera Hati, 2007.

Kasir, Ibnu. Taffîr Ibnu Kasîr, diterjemahkan oleh Salim Bahreisy, Said Bahreisy, Surabaya : PT Bina Ilmu, 2005.

Husain, Abi Ahmad Ibnu Faris Zakaria, Maqâyis alLugah, Jilid V, Beirut: Dâr al-Fikr, th.

Farraj, Ahmad Husain, A $\underline{h} k \hat{a} m$ al-Usrah fi al-Islâm, Beirut: Dâr al-Jami'iyyah, 1998.

Mandzur, Ibn. Lisân al-Arab, Kairo: Dâr al-Maârif, t.t.

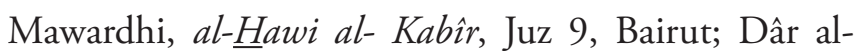
Kutub al-Ilmiyah.

Muhamad, Tengku Hasbi Ash Shiddieqi. Fiqih Mawaris, Semarang : PT Pustaka Riski Putra, 1997. Muhammad, Husnaini Makhluf. Kalimat Alquran
Tafsìr wa Bayân, Qahirah: Dâr al-Qalam, 1956.

Mutawali, Muhammad Syảrawî, Tafsîr Sya'rawî̀, Jilid 9, Jakarta: PT Khazanah Nusantara Agung, 2011.

Poerwadarminta, Kamus Umum Bahasa Indonesia, Jakarta : PN Balai Pustaka, 1966.

Qudamah, Ibnu, al-Mugni, Bairut : Dâr al-Kutub alIlmiyah.

al-Raghib, Ashfahani, Mưjam Mufradât al-Fâz Alquran, Beirut: Dâr al-Kutub al- Ilmiyah, 2013.

Saebani, Beni Ahmad, Fiqh Mawaris, Bandung : Pustaka Setia, 2009.

al-Shabuni, Muhammad Ali, Min Qumush al-Sunnah, Jakarta: Dâr al-Kutub al- Islamiyah, 1999.

Shihab, M. Qurasih, , Tafsir al-Mishbah, Pesan, Kesan dan Keserasian Alquran, Jakarta: Lentera Hati, 2002.

Syamsu, Andi Alam dan M. Fauzan. Hukum Pengangkatan Anak Perspektif Hukum Islam, Jakarta: Kencana Prenada Media Group, 2008.

Tea, Ari Kang, "Penyusunan Silsilah Nasab dan Urgensinya" https://www.facebook.com/notes/ kang-ari-tea/penyusunan-silsilah-nasab-danurgensinya/10152153520621715

Zuhaylî, Wahbah, Tafsìr al-Munîr fi al-Aqîdah wa Syarîah wa al-Manhaj, Juz 10, Beirut: Dâr al- Fikr, 2011.

t.p. "Hamil di Luar Nikah dan Masalah Nasab Anak Zina," Almanhaj.or.id/content/2099/slash/0/hamil di luar nikah dan masalah nasab anak zina, diunduh 23 Februari 2016.

t.p. "DNA Bukti Hubungan Nasab, Benarkah?" http://www.republika.co.id/berita/dunia-islam/ fatwa/13/01/29/mhdnq0-dna-bukti-hubungannasab-benarkah diunduh 23 Februari 2016.

republika.co.id/berita/dunia-islam/fatwa/13/01/29/mhdnq0-dnabukti-hubungan-nasab-benarkah, diunduh 23 November 2015. 